\title{
KERAGAMAN GENETIK VARIETAS PADI japonica DAN indica BERDASARKAN MARKA DNA TERKAIT MUTU RASA
}

\author{
PUjI LESTARI ${ }^{1}$, REFLINUR ${ }^{1}$, DODY DWI HANDOKO ${ }^{2}$, MASTUR ${ }^{1}$
}

${ }^{1}$ Balai Besar Penelitian dan Pengembangan Bioteknologi dan Sumber Daya Genetik Pertanian, Jalan Tentara Pelajar 3A, Bogor 16111 ${ }^{2}$ Balai Besar Penelitian Tanaman Padi, Jalan Raya Sukamandi 9, Subang 41256

\section{A B S T RACT}

PCR-based markers and evaluation of physicochemical properties should be addressed for the improvement of rice varieties with good eating dan cooking quality (EQ). This study aimed to examine the genetic diversity of rice varieties based on DNA markers related to physicochemical properties determining EQ. A total of 46 rice varieties consisting of 22 japonica varieties and 24 indica varieties were examined using 43 PCR-based markers. The results showed that polymorphic information content (PIC) ranged from 0.04 to 0.38 , in support of genetic diversity indices which ranged from 0.04 to 0.50 across total markers. Pairwise genetic similarity matrix ranged from 0.40 to 0.98 with the closest genetic distance was observed between two japonica varieties (Dongjin and Hwaseong) and the most distant one was between japonica and indica (Onnuri/Manmi with Cigeulis/Fatmawati). The unweighted neighbor-joining tree clustered the rice varieties into two major clades, indica and japonica, and subsequent subclades were differentiating according to the individual genetic background. The genetic diversity of rice from different subspecies and DNA markers for EQ can effectively be utilized for basic information and marker-assisted selection (MAS) for the development of improved varieties with good EQ in rice breeding program.

Key Words: eating quality, genetic diversity, japonica and indica rice varieties, DNA marker, neighbor-joining tree

\section{PENDAHULUAN}

Padi (Oryza sativa L.) merupakan tanaman pangan penting yang menjadi makanan pokok hampir separuh penduduk dunia. Padi merupakan komoditas penting karena karakter agronomi dan nutrisinya menyediakan lebih dari $20 \%$ kalori per kapita bagi penduduk dunia (Kubo \& Purevdorj, 2004). Padi budidaya juga memegang posisi unik karena merupakan tanaman pertama yang disekuen genomnya. Perkembangan ilmu genomika dan molekuler semakin membuka kesempatan berbagai studi dan pemanfaatannya untuk peningkatan genetik mutu padi (Garris et al., 2005).

Padi terbagi menjadi dua subspesies utama, yaitu indica dan japonica yang merupakan hasil domestikasi spesies nenek moyang, yaitu Oryza rufipogon (Doi et al., 2002; Cheng et al., 2003). Padi indica banyak dibudidayakan di Asia tropis (Asia Tenggara), dan japonica merupakan tanaman temperate di Asia Timur, dataran tinggi Asia Tenggara, dan Asia Selatan. Genotipe dan fenotipe padi indica dan japonica sangat berbeda. Bentuk butir padi dua subspecies tersebut berbeda. Butir padi indica cenderung panjang, ramping dan non-sticky setelah dimasak. Sebaliknya butir padi japonica pendek, cenderung bulat, dan nasinya sticky (Matsuo et al., 1997; Kohyama et al., 2016). Kepulenan beras masak/nasi biasanya dipengaruhi oleh kadar amilosa. Semakin rendah kandungan amilosa maka nasi semakin pulen. Pada umumnya nasi pulen mengandung amilosa sekitar $20 \%$ dan tidak lebih dari 25\% (Suprihatno et al., 2010). Nasi yang pulen, tidak terlalu basah atau kering, dan sebaliknya nasi pera, kering dan keras bila amilosanya tinggi. Beberapa karakter pembeda lainnya adalah warna daun, panjang rambut apical, reaksi fenol, kandungan amilosa dan lainnya yang sebagian menunjukkan karakter overlap antara kedua subspesies ini (Garris et al., 2005).

Gen-gen penyintesis pati berperan terhadap variasi fisika-kimia pati karena mempengaruhi jumlah dan struktur amilosa dan amilopektin butir padi. Secara genetik minimal satu gen mayor dan modifiernya mengontrol kandungan amilosa, protein, dan sifat pasta (rapid visco analyser, RVA) (Bao et al., 2006). Kandungan protein menentukan mutu rasa, dalam hal ini tekstur dan sifat keras bagian permukaan nasi. Alel dari RM4108-A dan RM4108-C berasosiasi signifikan dengan kandungan protein rendah yang menghasilkan mutu rasa bagus dan pulen (Hori et al., 2016). Variasi genetik gen penyintesis pati seperti gen waxy $(W x)$, sucrose synthase (SSI, SSIIa) dan starch branching enzyme (SBEIIa, SBEIIb) di indica dan japonica bermanfaat bagi upaya pengembangan varietas padi baru dengan kualitas pati yang lebih baik (Luo et al., 2015). Analisis molekuler ini melengkapi karakterisasi sifat fenotipe pati yang dilakukan antara varietas indica dan japonica (Tan et al., 2002; Kharabian-Masouleh et al., 2011, 2012; Lestari et al., 2013; Palanga et al., 2016).

Berbagai jenis marka molekuler seperti sequence tagged site (STS), simple sequence repeat (SSR), single nucleotide polymorphism (SNP) (termasuk cleaved amplified polymorphic sequence/CAPS, derived cleaved amplified polymorphic sequence/dCAPS, single nucleotide amplified polymorphism/SNAP), sequence characterized amplified region (SCAR), dan insertion/deletion (Indel), yang terkait dengan gen penyintesis pati telah dikembangkan dan diaplikasikan untuk analisis genetik, pemetaan pada populasi persilangan maupun evaluasi plasma nutfah. Sampai saat ini telah dikembangkan marka terkait gen penyintesis pati (Wx, SSI, SSIIa, SBEI, SBEIIa and SBEIIb) untuk identifikasi alel target pada varietas 
padi japonica dan indica (Bao et al., 2006; He et al., 2006; Luo et al., 2015), dan marka genetik SNP untuk genotyping dalam program pemuliaan padi dalam upaya meningkatkan kualitas pati (Yan et al., 2007; Tian et al., 2010). Untuk melengkapi marka DNA tersebut sejumlah marka SCAR terkait mutu rasa (Ohstubo et al., 2003), dan marka molekuler berdasarkan quantitative trait loci (QTL) dan gen kandidat yang mengontrol mutu rasa telah dikembangkan untuk evaluasi mutu rasa beras japonica dan indica (Lestari et al., 2009, 2015).

Kemajuan pengembangan dan pemanfaatan marka DNA terkait mutu rasa dan sifat fisiko-kimia lainnya telah banyak dilakukan di negara lain. Namun analisis diversitas varietas indica Indonesia dan japonica dengan marka DNA terkait mutu rasa tersebut masih sangat terbatas. Untuk itu penelitian ini bertujuan untuk mengidentifikasi variasi genetik varietas padi indica dari Indonesia dan japonica berdasarkan marka DNA terkait mutu rasa.

\section{MET O DE}

Sebanyak 46 varietas padi terdiri atas 22 varietas japonica yang sebagian besar berasal dari Korea dan 24 varietas indica dari Indonesia yang memiliki mutu rasa dari rendah sampai tinggi digunakan dalam penelitian ini (Tabel 1). Informasi mutu rasa varietas dalam studi ini berdasarkan uji organoleptik hasil penelitian sebelumnya (Lestari et al., 2009; Lestari et al., 2015). Analisis molekuler dilakukan di Seoul National University (SNU), dan Lab, Biologi Molekuler, Balai Besar Penelitian dan Pengembagan Bioteknologi dan Sumber Daya Genetik Pertanian (BB Biogen).

DNA genomik diisiolasi dari daun muda dan sehat menggunakan metode cetyl trimethy lammonium bromide (CTAB) mengikuti protokol Murray dan Thompson (1980). Daun digerus menjadi bubuk halus menggunakan pestle dan mortar dengan bantuan nitrogen cair. DNA yang diperoleh dilarutkan dalam $100 \mu \mathrm{l} 1 \mathrm{X}$ bufer TE (pH 8,0). Kemurnian dan kuantitas DNA diukur menggunakan NanoDrop 2000 spektrofotometer pada panjang gelombang 260/280 dan 230/280 nm. DNA divisualisasikan melalui elektroforesis gel agarosa $0,8 \%$ untuk memastikan kualitas dan kuantitasnya.

Sebanyak 43 primer dari pengembangan sebelumnya baik dari hasil desain maupun adopsi dari kelompok peneliti lain seperti dilaporkan oleh Lestari et al. (2015), digunakan untuk mengamplifikasi (PCR) marka DNA dari semua varietas dalam penelitian ini (Tabel 2). Volume PCR total adalah $20 \mu \mathrm{l}$ dengan komposisi sebagai berikut: DNA 20 $\mathrm{ng} / \mu \mathrm{l}$ sebanyak $1 \mu \mathrm{l}, 10 \mathrm{X}$ bufer mengandung $25 \mathrm{mM} \mathrm{MgCl}$, 2,5 mM dNTPs sebanyak $1 \mu \mathrm{l}, 1$ Unit Taq Polymerase (Intron Biotechnology, Korea), dan primer forward dan reverse (10 $\mathrm{mM}$ ) masing-masing $1 \mu \mathrm{l}$. Suhu penempelan mengikuti suhu melting tiap primer. Secara umum amplifikasi PCR terdiri dari denaturasi awal pada $95^{\circ} \mathrm{C}$ selama 5 menit, total 35 siklus dengan program denaturasi 1 menit pada $95^{\circ} \mathrm{C}$, annealing 30 detik pada $55^{\circ} \mathrm{C}$ (sesuai dengan suhu melting tiap primer) dan perpanjangan salama 1 menit pada $72^{\circ} \mathrm{C}$, dan perpanjangan final pada $72^{\circ}$ selama 7 menit. Produk PCR untuk primer STS, SCAR, dan SNP (CAPS/dCAPS) divisualisasikan pada gel agarosa $3 \%$. Penggunaan gel agarosa dengan persentase kecil ini telah cukup untuk memigrasikan amplikon tersebut yang berbasis alel dan/atau keberadaan ukuran produk target (ada dan tidak ada pita DNA). Amplikon dari primer SSR dan Indel dielektroforesis pada poliakrilamid 8\% non denaturasi dan direndam dalam larutan ethidium bromide (Model MGV202-33, CBS Scientific Co,, Del Mar, CA, USA).

Tabel 1. Varietas padi japonica dan indica yang digunakan dalam penelitian ini.

\begin{tabular}{|c|c|c|c|}
\hline $\begin{array}{l}\text { Nama } \\
\text { varietas }\end{array}$ & Subspesies & $\begin{array}{l}\text { Asal } \\
\text { negara }\end{array}$ & $\begin{array}{r}\text { Mutu rasa } \\
\text { berdasarkan uji } \\
\text { hedonik }^{*}\end{array}$ \\
\hline Koshihikari & japonica & Jepang & 4,25 \\
\hline Gopum & japonica & Korea Selatan & 4,18 \\
\hline Samgwang & japonica & Korea Selatan & 4,28 \\
\hline Ilpum & japonica & Korea Selatan & 4,39 \\
\hline Geuman & japonica & Korea Selatan & 4,20 \\
\hline Seonong4 & japonica & Korea Selatan & 4,12 \\
\hline Dongjin & japonica & Korea Selatan & 3,95 \\
\hline Hwaseong & japonica & Korea Selatan & 3,80 \\
\hline Hwacheong & japonica & Korea Selatan & 3,68 \\
\hline Samdeok & japonica & Korea Selatan & 3,46 \\
\hline Baekjinju1 & japonica & Korea Selatan & 4,10 \\
\hline Nakdong & japonica & Korea Selatan & 3,75 \\
\hline Onnuri & japonica & Korea Selatan & 3,95 \\
\hline Manmi & japonica & Korea Selatan & 3,90 \\
\hline Chucheong & japonica & Korea Selatan & 4,00 \\
\hline Hitomebore & japonica & Jepang & 4,15 \\
\hline Palkong & japonica & Korea Selatan & 3,17 \\
\hline Giho & japonica & Korea Selatan & 3,60 \\
\hline Samnam & japonica & Korea Selatan & 3,05 \\
\hline Hexi41 & japonica & Cina & 2,80 \\
\hline Sinkeumo & japonica & Korea Selatan & 3,60 \\
\hline Dobong & japonica & Korea Selatan & 2,76 \\
\hline Rojolele & indica & Indonesia & 4,10 \\
\hline Ciliwung & indica & Indonesia & 3,90 \\
\hline Sintanur & indica & Indonesia & 4,10 \\
\hline Cimelati & indica & Indonesia & 4,05 \\
\hline Cigeulis & indica & Indonesia & 3,90 \\
\hline Memberamo & indica & Indonesia & 4,10 \\
\hline Tukad Balian & indica & Indonesia & 4,15 \\
\hline Conde & indica & Indonesia & 4,00 \\
\hline Angke & indica & Indonesia & 3,90 \\
\hline Batang Gadis & indica & Indonesia & 4,00 \\
\hline Ciherang & indica & Indonesia & 3,95 \\
\hline Batanghari & indica & Indonesia & 3,80 \\
\hline Fatmawati & indica & Indonesia & 3,80 \\
\hline Cibodas & indica & Indonesia & 3,60 \\
\hline Kalimutu & indica & Indonesia & 3,60 \\
\hline Cirata & indica & Indonesia & 3,40 \\
\hline Cisokan & indica & Indonesia & 3,45 \\
\hline Ramos & indica & Indonesia & 3,10 \\
\hline Batang Piaman & indica & Indonesia & 3,94 \\
\hline Singkil & indica & Indonesia & 2,95 \\
\hline Konawe & indica & Indonesia & 3,05 \\
\hline Logawa & indica & Indonesia & 3,25 \\
\hline Pepe & indica & Indonesia & 4,25 \\
\hline Jatiluhur & indica & Indonesia & 2,20 \\
\hline
\end{tabular}

Pola pita hasil genotyping semua primer diskoring sesuai dengan jumlah alel yang muncul dalam total koleksi varietas padi. Data hasil skor ini dianalisis statistik terkait dengan total alel, alel dominan, alel jarang, heterozigositas, genetic diversity indices dan Polymorphic Information Content (PIC), PIC dan heterozigositas dihitung untuk total varietas dan primer (Liu, 2001). Genetic diversity indices dan analisis klaster dibuat berdasarkan estimasi metode Nei dengan analisis neighbor-joining. Keragaman genetik juga diestimasi pada intra dan inter subspesies serta antar varietas. Untuk mendukung formasi klaster, dilakukan analisis bootstrap 1000 permutasi menggunakan PowerMarker V3.25 (Felsenstein, 1985; Liu \& Muse, 2005). Analisis asosiasi antara data marka molekuler dan sifat fisika-kimia dan organoleptik dilakukan menggunakan perangkat lunak Tassel V.5 .0. (Bradbury et al., 2007). 
Tabel 2. Marka molekuler yang digunakan dalam penelitian ini.

\begin{tabular}{|c|c|c|c|}
\hline \multirow{2}{*}{$\begin{array}{l}\text { Nama } \\
\text { Marka PCR }\end{array}$} & \multirow{2}{*}{ Jenis Marka } & \multicolumn{2}{|l|}{ Urutan sekuen primer } \\
\hline & & Forward (5'-3') & Reverse (5'-3') \\
\hline \multicolumn{4}{|c|}{ Ohstubo et al. $(2002,2003)$; Ohtsubo dan Nakamura $(2007)$} \\
\hline A6 & STS & CCAGCTGTACGCCTGTACTAC & CCAGCTGTACGTCTTCCCCAGC \\
\hline A7 & STS & TGCCTCGCACCAGAAATAG & TGCCTCGCACCATGAG \\
\hline B1 & STS & GTTTCGCTCCTACAGTAATTAAGGG & GTTTCGCTCCCATGCAATCT \\
\hline B43 & STS & GGCCGGCATGACTCAC & ACTGGCCGGCATCAAGAC \\
\hline F6 & STS & ACСАСТССАТАТАТАТСАТССАAAG & ACСАСТCСАТАТСACСACAAGG \\
\hline G4 & STS & GAGACCGATATGCGATTC & GTGGTGTTTAGATCCAGAGACTTA \\
\hline G22 & STS & CTCACTCAAATTTACAGTGCATTTTCTTG & AGGGCCATGATACAAGACTCTGT \\
\hline G28 & STS & GGCGGTCGTTCTGCGAT & GGAGAATCCCACAGTAAGTTTTTCTTTG \\
\hline J6 & STS & GTCGGAGTGGTCAGACCG & GTCGGAGTGGATGGAGTAGC \\
\hline M2CG & STS & ACAACGCCTCCGATGA & ACAACGCCTCCGACAACAAGAT \\
\hline M11 & STS & GTCCACTGTGACCACAACAT & GTCCACTGTGGGGATTGTTC \\
\hline P5 & STS & ACAACGGTCCGTCCTTGCTT & ACAACGGTCCAACAGATACTTTTGA \\
\hline S13 & STS & GTCGTTCCTGTGGTTAGGACAGGGT & GTCGTTCCTGCTGGTGTCTCAGAT \\
\hline T16 & STS & GGTGAACGCTGTAGTTGGAATATA & GGTGAACGCTCAGATTTAAATATAAT \\
\hline WK9 & STS & CCCGCAGTTAGATGCACCATT & CCGCAGTTAGATCAAGTGGC \\
\hline E30 & STS & TACCTGGTTGATGTATACAGATCTGGTT & ATCCCTCGATCCСTCTAGCATTAT \\
\hline B7 & STS & CAGGTGTGGGTTACAAGGATGA & CAGGTGGTTCACGGCCTTT \\
\hline G49A & STS & AATCCAGACATGAAATTTATATGCAGATA & AATCCAGACATGTTGTCCTCAATTTTTG \\
\hline G81 & STS & TACCTGAACCAGCAAGCATGCGCG & TACCTGAACCAGTATAATCTTTG \\
\hline P3 & STS & AACGGGCCAAAAACGGAGGT & AACGGGCCAACGCAG \\
\hline \multicolumn{4}{|c|}{ Bao et al. (2006a,b) } \\
\hline Wx (SNP) & CAPS/AccI & CTTTGTCTATCTCAAGACAC & TTTCCAGCCCAACACCTTAC \\
\hline SS1 (SSR) & SSR & GATCCGTTTTTGCTGTGCCC & ССTCCTCTCCGCCGATCCTG \\
\hline SBE1 (SSR) & SSR & ATTTCTTTGGCCACAGGCGA & CCCAGATTCGGAACAAGAAC \\
\hline SBE1 (STS) & STS & GAGTTGAGTTGCGTCAGATC & AATGAGGTTGCTTGCTGCTG \\
\hline SBE2 (SNP) & dCAPS/SpeI & GTCTTGGACTCAGATGCTGGACTC & ATGTATAACTGGCAGTTCGAACGG \\
\hline \multirow{2}{*}{ SSIIa } & SNP & F7: CTGGATCACTTCAAGCTGTACGAC & R1: GCCGGCCGTGCAGATCTTAAC \\
\hline & & F22: CAAGGAGAGCTGGAGGGGGC & R21: ACATGCCGCGCACCTGGAAA \\
\hline \multicolumn{4}{|c|}{ Lestari et al. (2009) } \\
\hline S3cI & Indel & CCACTCTCATGTCCTTGAAC & GCCATGACATTTGGACAT \\
\hline S3cII & dCAPS/TaqI & TTCCATGATGTGCCACTCTC & GGACAAATGTTTTCAGTGAATAAAT \\
\hline TreB & Indel & CACTCCAGTTCCTGCTCAAA & CACCTCCAAAACGAATATGG \\
\hline AMs & SSR & СТTCCAAGGACCCСАTCCT & СССAACATCTCCGTCAGAAT \\
\hline GPA & SSR & CCAAATACGCGGCCTTCT & AGTTTCTGGGCTCGGAGGA \\
\hline GBSS1 & SSR & CAAATAGCCACССАСАССАС & CTTGCAGATGTTCTTCCTGATG \\
\hline $\mathrm{AcPh}$ & dCAPS/MseI & AGTTGTGGTTTAAGCATAGG & ATTGTCCTTTTCTTTAAAGTTTATTA \\
\hline CBG & SSR & AGCTTCCCTAATGGCTTCGT & ATTTGCCAACTTTTGGATGG \\
\hline SH51 & dCAPS/SpeI & ATTCTTGATGAAAATAATTAACTAG & GGTTAACCATCTTATAAAATTTGTC \\
\hline \multicolumn{4}{|c|}{ He et al. (2006) } \\
\hline SS1 (STS) & STS & TCTAGATTGCTACACGTGAGAGG & TCTCCACGATAACTTCCACC \\
\hline SBE3 (STS) & STS & TCGGTCAATTCGGTTAGTCTCCTC & ACATCCTCTAGCATACTGGCGACTC \\
\hline SssIIa & STS & TCTAGATTGCTACACGTGAGAGG & GGAGCCACCTGTAAAGCGTG \\
\hline Isa & STS & CCTGTCTTGCACGTGCGGTA & GCACGGTTCTGATGTACGAGAG \\
\hline Pul3 (3'end) & STS & GGGTTCGCTTTCACAACACAG & GTCACGACATAAGAGAAGCTGC \\
\hline Pul5 (5'end) & STS & AGTTCGCTAGTCATCTGCTCG & CCACATGTCCTTGTCTCCACTT \\
\hline \multicolumn{4}{|c|}{ Zeng et al. (2007) } \\
\hline $\mathrm{P} 2$ & STS & ATTAGCCGGTAAATGGATGAGTTC & AAGCAATACTAАТСССТССАААСС \\
\hline P3A & STS & AATCCAACGCATCAAGGCTGGC & ACAATGCCAAACACCAGGAACTCG \\
\hline P4 & STS & TGAGCTTTACСТCСССТССТАACC & ТССАССТТТСТСТСТСАТСССАС \\
\hline P7 & STS & AGTTAAACAACCTCCССACTGC & GGGTAGGATAGGGGATAAGGAGC \\
\hline \multicolumn{4}{|c|}{ Kobayashi et al. (2008) } \\
\hline KA43 & SSR & CCTTTCTGAATGCGGAATTT & GAAATGATGGCATGGGAGAT \\
\hline \multicolumn{4}{|c|}{ Lestari et al. (2015) } \\
\hline MAD & STS & TAACAACCACGGCCGAGAA & GAGCGTTCTTTTCTTTCGGTA \\
\hline HP & STS & TGGAGGAGATGTACGTCGAG & GAAGTCGAGGTGGTCCATGA \\
\hline PP2 & CAPS/MseI & TTTGAATAGGTCCACTGCTT & CСATGCATCTCATTAGTCAA \\
\hline PFruc & dCAPS/EcoRI & CTTCTTCTTCGGGTGTCTCG & TGTTAAGTCCAGGGCAGAGG \\
\hline Aglu & STS & ССTCTGGAATCTTGCTATTTAGG & ATCCGCTAGATCACTGACAAA \\
\hline LDS & STS & CGAGGAGACAGACAGCATCA & GATGCAGCAGCCATGAGTT \\
\hline BE2 & CAPS/SpeI & GCCCCGAACATGATTCTA & GGCTTTACCGACCTTACTGT \\
\hline BE6 & $\mathrm{dCAPS} / \mathrm{HphI}$ & TACCCCAGTTAAGTGTCTGTAAAGG & GAAGAGAGCGCAAGAATCCATTGTT \\
\hline
\end{tabular}

\section{HASIL DAN PEMBAHASAN}

Total alel yang terdeteksi di antara 46 varietas dari total 43 primer adalah 92 dengan rerata 2 alel per lokus. Contoh pola pita dan polimorfisme yang dihasilkan beberapa primer dalam studi ini ditampilkan pada Gambar 1. Frekuensi alel dominan $(>30 \%)$ diidentifikasi pada 46 lokus dengan rerata 0,74 dengan nilai tertinggi 0,98 pada B7 dan SH51. Marka DNA lainnya yang menghasilkan alel mayor $>90 \%$ adalah B43, P5, dan SSI sebaliknya Aglu, LDS, dan P7 memiliki alel mayor terendah yaitu 0,5. 

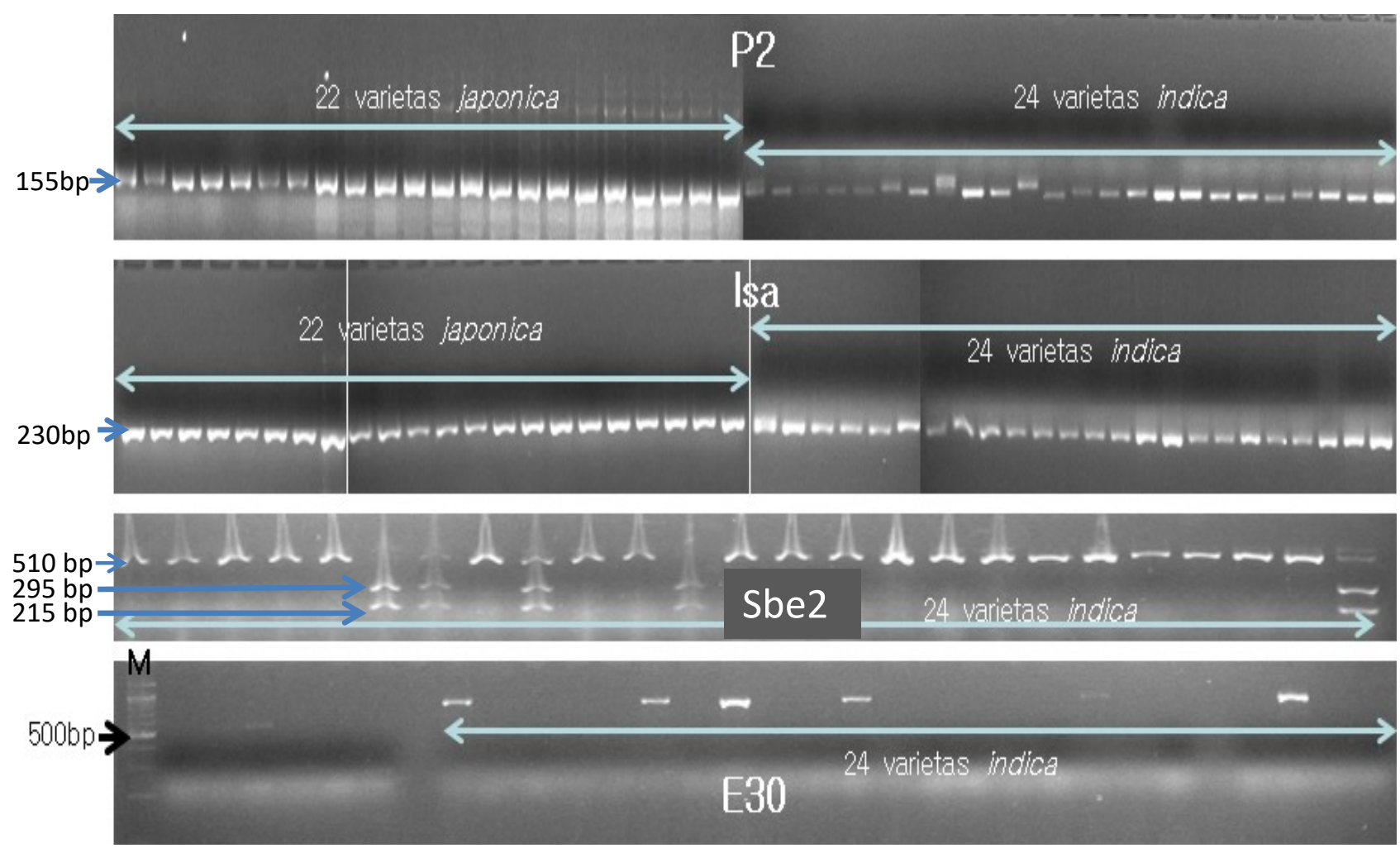

Gambar 1. Contoh pola polimorfisme antara padi japonica dan indica menggunakan marka DNA. Primer P2 (148 dan 155 bp), Isa (220 dan 230 bp), dan Sbe2 (510, 295 dan 215 bp) adalah marka kodominan yang dilihat berdasarkan perbedaan ukuran alel. E30 (790 bp) adalah marka dominan dengan sistem skoring "ada" dan "tidak ada pita".

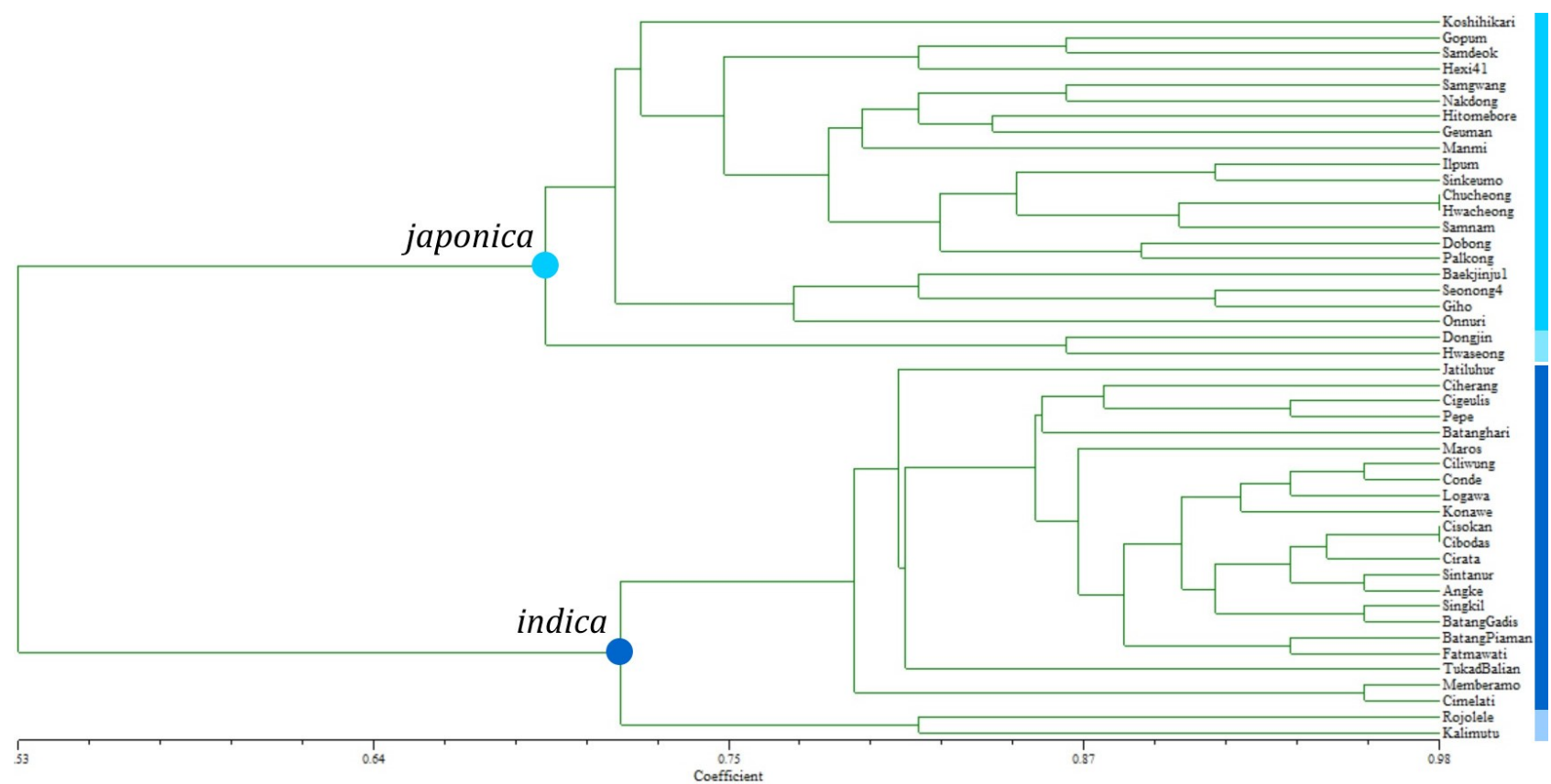

Gambar 2. Dendrogram kekerabatan genetik 46 varietas padi berdasarkan 43 marka DNA.

Polymorphic Information Content (PIC) sebagai salah satu indikator tingkat polimorfisme marka molekuler menunjukkan rerata rendah pada total marka $(0,26)$ dengan selang antara 0,04 dan 0,38 . Marka DNA yang memiliki PIC tertinggi adalah P7, Isa, Aglu, dan LDS. Ringkasan statistik total 43 primer yang diobservasi dalam studi ini ditampilkan pada Tabel 3. Nilai PIC tinggi cenderung diikuti oleh indeks gene diversity yang tinggi pula dan sebaliknya. Rerata indek gene diversity pada total koleksi varietas padi berdasarkan total primer adalah 0,33 dengan nilai terendah 0,04 (primer B7, SH51, CBG, dan P2) dan tertinggi adalah pada 0,5 (A7, Aglu, BE3, LDS, Isa, P7, Pul3, dan KA43).

Meskipun marka DNA memiliki PIC rendah, namun berpotensi cukup baik sebagai marka untuk deteksi mutu rasa baik pada japonica (Lestari et al., 2009) maupun indica (Lestari et al., 2015). Oleh karena itu dalam studi ini pemanfaatan marka DNA dalam 
sebuah formulasi set marka lebih dianjurkan daripada aplikasi marka tunggal. Hasil ini didukung fakta bahwa alel yang dihasilkan oleh marka DNA tersebut cenderung bialel dalam koleksi varietas japonica dan indica ini. Marka DNA yang digunakan telah diaplikasikan pada padi, yaitu primer SCAR yang dikembangkan dari RAPD (Ohstubo et al., 2002, 2003) dan primer jenis lain yang berbasis gen spesifik ataupun QTL yang berasosiasi dengan sifat fisikakimia (Bao et al., 2006; He et al., 2006; Lestari et al., 2009, 2015).

Hasil analisis filogeni menunjukkan bahwa marka DNA yang digunakan dalam penelitian ini mampu menghasilkan diferensiasi subspesies japonica dan indica termasuk diferensiasi varietas berdasarkan latar belakang genetiknya. Analisis filogeni 46 varietas padi menunjukkan adanya variasi total varietas dengan koefisien kesamaan genetik dari 0,37 sampai 1,00 (Gambar 2), Total varietas terbagi menjadi 2 klaster utama, yang secara jelas memisahkan varietas japonica (22 varietas) dan indica (24 varietas), dalam kelompok japonica, ada 2 subklaster yang terdiri atas mayoritas varietas japonica dan 2 varietas lainnya (Dongjin dan Hwaseong) di subklaster kedua. Varietas Jepang Hitomebore dan varietas Cina (Hexi41) cenderung mengelompok dengan varietas Korea daripada Koshihikari, varietas premium Jepang lainnya, Koshihikari dengan mutu rasa enak di Jepang (Lestari et al., 2009) dapat dibedakan dari koleksi varietas Korea Selatan (Gambar 2). Demikian juga varietas japonica dari Korea Selatan, Seonong4 dengan mutu rasa tinggi cenderung dekat dengan kelompok mutu rasa cukup tinggi. Ada 2 varietas japonica yang sangat dekat jarak genetiknya $(0,98)$ yaitu varietas Dongjin dan Hwaseong. Kesamaan genetik terendah pada japonica ternyata terdeteksi antara varietas Korea dengan padi introduksi seperti Koshihikari-Seonong4, Onnuri-Hexi41(0,58), dan Hwaseong-Hitomebore $(0,58)$. Koshihikari (japonica) sebagai beras dengan mutu rasa tinggi dapat menjadi sumber tetua potensial untuk perbaikan mutu rasa beras Indonesia yang mayoritas indica. Mengingat perbedaan jarak genetik yang terlalu jauh dapat menjadi genetic barrier, persilangan lintas subspesies antara japonica dan indica, maka diperlukan uji coba dengan cukup banyak persilangan maupun resiprok.

Hal yang sama terjadi pada kelompok indica. Mayoritas varietas mendominasi subklaster pertama (22 varietas) dan dua varietas lainnya (Rojolele dan Kalimutu) cenderung terpisah di subklaster kedua. Hasil ini kemungkinan disebabkan adanya pengaruh kemiripian karakter fisikokimia lainnya. Rojolele (kandungan amilosa 22,53\% dan Kalimutu (kandungan amilosa 23,04\%) memiliki kandungan amilosa rendah sampai sedang (Avaro et al., 2009) yang mirip dengan tropical japonica, didukung oleh informasi molekuler marka DNA ini. Kandungan protein Rojolele $(4,1 \%)$ dan Kalimutu $(3,6 \%)$ juga tidak terlalu jauh. Terdapat kecenderungan varietas lokal dengan karakter mirip memiliki jarak genetik lebih dekat dibandingkan dengan varietas komersil populer seperti Ciherang. Namun Fatmawati mempunyai kedekatan dengan varietas lokal (Batang Piaman) mungkin karena latar belakang genetik dari sistem pedigreenya.

Tabel 3. Ringkasan statistik total 43 primer yang diobservasi pada 46 varietas padi.

\begin{tabular}{|c|c|c|c|}
\hline Primer & $\begin{array}{c}\text { Frekuensi alel } \\
\text { mayor }\end{array}$ & $\begin{array}{c}\text { Indek Diversitas } \\
\text { Genetik }\end{array}$ & PIC \\
\hline A7 & 0,52 & 0,50 & 0,37 \\
\hline B1 & 0,89 & 0,19 & 0,17 \\
\hline B43 & 0,91 & 0,16 & 0,15 \\
\hline E30 & 0,57 & 0,49 & 0,37 \\
\hline F6 & 0,59 & 0,48 & 0,37 \\
\hline G4 & 0,80 & 0,31 & 0,27 \\
\hline G22 & 0,76 & 0,36 & 0,30 \\
\hline G28 & 0,76 & 0,36 & 0,30 \\
\hline $\mathrm{J} 6$ & 0,65 & 0,45 & 0,35 \\
\hline M11 & 0,83 & 0,29 & 0,25 \\
\hline M2CG & 0,83 & 0,29 & 0,25 \\
\hline P5 & 0,96 & 0,08 & 0,08 \\
\hline S13 & 0,59 & 0,48 & 0,37 \\
\hline T16 & 0,89 & 0,19 & 0,17 \\
\hline WK9 & 0,78 & 0,34 & 0,28 \\
\hline P3 & 0,70 & 0,42 & 0,33 \\
\hline B7 & 0,98 & 0,04 & 0,04 \\
\hline G49A & 0,74 & 0,39 & 0,31 \\
\hline G81 & 0,65 & 0,45 & 0,35 \\
\hline TreB & 0,65 & 0,45 & 0,35 \\
\hline SSIIa & 0,74 & 0,39 & 0,31 \\
\hline Ams & 0,83 & 0,29 & 0,25 \\
\hline GPAs & 0,87 & 0,23 & 0,20 \\
\hline $\mathrm{AcPh}$ & 0,72 & 0,41 & 0,32 \\
\hline S3cI & 0,83 & 0,29 & 0,25 \\
\hline S3CII & 0,65 & 0,45 & 0,35 \\
\hline GBSS1 & 0,78 & 0,34 & 0,28 \\
\hline SH51 & 0,98 & 0,04 & 0,04 \\
\hline PP2 & 0,87 & 0,23 & 0,20 \\
\hline PFruc1 & 0,61 & 0,48 & 0,36 \\
\hline Aglu & 0,50 & 0,50 & 0,38 \\
\hline LDS & 0,50 & 0,50 & 0,38 \\
\hline BE3 & 0,54 & 0,50 & 0,37 \\
\hline Isa & 0,50 & 0,50 & 0,38 \\
\hline SSI & 0,96 & 0,08 & 0,08 \\
\hline Sbe2 & 0,59 & 0,48 & 0,37 \\
\hline P3A & 0,93 & 0,12 & 0,11 \\
\hline P4 & 0,96 & 0,08 & 0,08 \\
\hline P7 & 0,50 & 0,50 & 0,38 \\
\hline Pul3 & 0,54 & 0,50 & 0,37 \\
\hline KA43 & 0,52 & 0,50 & 0,37 \\
\hline CBG & 0,98 & 0,04 & 0,04 \\
\hline P2 & 0,98 & 0,04 & 0,04 \\
\hline Rataan & 0,74 & 0,33 & 0,26 \\
\hline
\end{tabular}

Secara umum Kalimutu memiliki rataan kesamaan genetik paling rendah dengan varietas lain. Variasi yang luas yang terlihat pada varietas indica dapat disebabkan oleh bervariasinya ekosistem penanaman di Indonesia misalnya di lahan sawah, tadah hujan dan rawa (Lestari et al., 2014). Secara keseluruhan antara varietas japonica dan indica, koefisien kesamaan yang paling rendah $(0,4)$ dalam arti jarak genetik paling jauh ditemukan antara varietas japonica dan indica baik varietas elit maupun lokal, khususnya Onnuri atau Manmi dengan Cigeulis atau Fatmawati. Jadi varietas yang memiliki sifat fisiko-kimia diantara indica dan japonica akan cenderung dekat secara genetik dengan varietas subspesies lainnya meskipun tetap mengelompok dalam subspesies utamanya. 
Varietas Onnuri atau Manmi (japonica) dengan Cigeulis atau Fatmawati (indica) memiliki jarak genetik yang jauh. Subklaster varietas japonica mengelompokkan varietas Korea (Gopum dan Samdeok) dan Cina (Hexi41), memiliki jarak genetik cukup jauh dengan padi Indonesia, sehingga dapat menjadi alternatif tetua persilangan. Dalam hal ini, perlu ditemukan solusi atas kendala genetik (genetic barrier) persilangan antara padi indica dan japonica.

Perbedaan antara varietas padi dalam studi ini menunjukkan status keragaman genetik yang luas antara japonica dan indica yang memisahkan keduanya berdasarkan subspecies. Informasi polimorfisme berdasarkan marka DNA ini terbukti mendukung diferensiasi dua subspesis padi berdasarkan karakter umum fenotip biji, habitat asli, dan level genetik khususnya gen ontologi dari laporan sebelumnya (Matsuo et al., 1997; Cheng et al., 2003; Johns \& Mao, 2007). Keragaman genetik padi indica Indonesia lebih rendah dibandingkan dengan padi japonica. Hal ini mungkin karena sebagian besar varietas yang dilepas diperoleh dari varietas yang secara luas ditanam di berbagai daerah dan dari varietas asli Indonesia. Beberapa varietas unggul baru (VUB) padi di Indonesia berasal dari tetua persilangan jenis IR yang dikembangkan dari International Rice Research Institute. Sebagai contoh, asal persilangan Conde adalah IR646/IRBB7, Cigeulis dari persilangan Ciliwung/Cikapundung//IR64, dan varietas Ciliwung dikembangkan dari IR38//2*Pelita I-1/IR4744-1284-1-2. Salah satu tetua persilangan dari Ciherang, Cigeulis, dan Pepe diketahui adalah IR64. Demikian juga varietas lokal padi yang cenderung spesifik ditanam di daerah tertentu dengan peluang kecil adanya pengaruh gene flow. Untuk pemuliaan padi, keragaman genetik padi indica Indonesia perlu diperluas melalui introduksi plasma nutfah dari berbagai daerah asal termasuk Korea, Jepang dan Cina.

\section{KE S I M P U L A N}

Rataan alel mayor, PIC, dan genetic diversity indices tergolong rendah. Matriks kesamaan genetik menunjukkan adanya jarak genetik antar varietas japonica dan indica Indonesia sehingga dapat dipertimbangkan sebagai tetua persilangan. Analisis klaster berdasarkan marka DNA berhasil mengelompokkan varietas padi menjadi dua klaster utama, indica dan japonica, dan subklaster selanjutnya memisah menurut latar belakang genetik individu.

\section{DAFT AR REFERENSI}

Avaro MRA, Tong L, Yoshida T. 2009. A simple and low-cost method to classify amylose content of rice using a standard color chart. Plat Production Science. 12:97-99.

Bao JS, Corke H, Sun M. 2006a. Microsatellites, single nucleotide polymorphisms and a sequence tagged site in starchsynthesizing genes in relation to starch physicochemical properties in nonwaxy rice (Oryza sativa L.). Theoretical Applied Genetics. 113: 1185-1196.

Bao JS, Corke H, Sun M. 2006b. Nucleotide diversity in starch synthase IIa and validation of single nucleotide polymorphisms in relation to starch gelatinization temperature and other physicochemical properties in rice (Oryza sativa L.). Theoretical Applied Genetics. 113: 1171-1183.

Bradbury PJ, Zhang Z, Kroon DF, Casstevens TN, Ramdoss Y, Buckler ES. 2007. TASSEL: Software for association mapping of complex traits in diverse samples. Bioinformatics. 23:2633-2635.

Cheng CY, Motohashi R, Tsuchimoto S, Fukuta Y, Ohtsubo H, Ohtsubo E. 2003. Polyphyletic origin of cultivated rice: based on the interspersion pattern of SINEs. Molecular Biology and Evolution. 20: 67-75.

Doi K, Sobrizal K, Ikeda K, Sanchez PL, Kurakazu TA. 2002. Developing and evaluating rice chromosome segment substitution lines, pp. 275-287 In IRRI Conference September, 16-19, 2002, International Rice Research Institute, Beijing, China.

Felsenstein J. 1985. Confident limit on phylogenies: An approach using the bootstrap. Evolution.39: 783-791.

Garris AJ, Tai TH, Coburn J, Kresovich S, McCouch M. 2005. Genetic structure and diversity in Oryza sativa L. Genetics. 169: 16311638.

He Y, Han Y, Jiang L, Xu C, Lu J, Xu M. 2006. Functional analysis of starch-synthesis genes in determining rice eating and cooking qualities. Molecular Breeding.18:277-290.

Hori K, Suzuki K, Iijima K, Ebana K. 2016. Variation in cooking and eating quality traits in Japanese rice germplasm accessions. Breeding Science. 66(2): 309-318.

Johns MA and Mao L. 2007. Differentiation of two rice subspecies indica and japonica: a Gene Ontology perspective. Functional and Integrative. Genomics. 7(2): 135-151.

Kharabian-Masouleh A, Waters DL, Reinke RF,Henry RJ. 2011. Discovery of polymorphisms in starch-related genes in rice germplasm by amplification of pooled DNA and deeply parallel sequencing. Plant Biotechnology Journal. 9:1074-1085.

Kharabian-Masouleh A, Waters DLE, Reinke RF, Ward R, Henry RJ. 2012. SNP in starch biosynthesis genes associated with nutritional and functional properties of rice. Scientific ReportUk. 2:557-565.

Kobayashi A, Tomita K, Yu F, Takeuchi Y, Yano M. 2008. Verification of quantitative trait locus for stickiness of cooked rice and amylose content by developing near-isogenic lines. Breeding Science. 58: $235-242$.

Kohyama K, Sodhi NS, Suzuki K, Sasaki T. 2016. Texture evaluation of cooked rice prepared from Japanese cultivars using two-bite instrumental test and electromyography. Journal of Texture Studies. 47: 188-198.

Kubo M, Purevdorj M. 2004.The future of rice production and consumption. Journal of Food Distribution Research. 35: 128142.

Lestari P, Ham TH, Lee HH, Woo MO, Jiang WJ, Chu SH, Kwon SK, Ma KH, Lee JH, Cho YC, Koh HJ. 2009. PCR marker-based evaluation of eating quality of cooked rice (Oryza sativa L,). Journal of Agriculture and Food Chemistry. 57 (7): 2754-2762.

Lestari P, Koh HJ. 2013. Evaluasi kandungan protein dan sifat pasta beras japonica dengan marka DNA. Berita Biologi. 12(2): 141152.

Lestari P, Reflinur, Koh HJ. 2014. Prediction of physicochemical proeprties of Indonesian indica rice using molecular markers. HAYATI Journal of Biosciences. 21(2): 76-86.

Lestari P, Jiang W, Chu SH, Reflinur, Sutrisno, Kusbiantoro B, Kim B, Piao R, Cho YC, Koh HJ. 2015. DNA markers for eating quality of indica rice in Indonesia. Plant Breeding. 134: 40-48.

Liu J. 2001. Power Marker V3.25 Manual, http://www. powermarker. net.

Liu K, Muse SV. 2005. PowerMarker: integrated analysis of environment for genetic diversity in core collection accessions of wild barley, Hordeum vulgare ssp, spontaneum. Hereditas.136: 67-73.

Luo J, Jobling SA, Millar A, Morell MK, Li Z. 2015. Allelic affect on starch structure and properties of six starch biosynthesis genes in a rice recombinant inbred line population. Rice. 8: 15.

Matsuo T, Futsuhara Y, Kikuchi F, Yamaguchi H. 1997. Science of the Rice Plant, Food and Agriculture. Policy Research Center, Tokyo.

Murray MG, Thompson WF. 1980. Rapid isolation of high molecular weight DNA. Nucleic Acids Research. 8: 4321-4325.

Ohstubo K, Nakamura S, Imamura T. 2002. Development of the primer sets for identification of a rice variety, Koshihikari by PCR. Nippon Nogeikagaku Kaishi. 76: 388-397. 
Ohstubo K, Nakamura S, Okadome H. 2003. Investigation on estimation of rice palatability by DNA analysis (studies on estimation of rice palatability by DNA analysis part I). Nippon Nogeikagaku Kaishi. 50:122-132.

Ohtsubo K, Nakamura S. 2007. Cultivar identification of rice (Oryza sativa $\mathrm{L}$,) by PCR application to processed rice product. Journal of Agricultural Food and Chemistry. 55(4): 1501-1509.

Palanga KK, Traore K, Bimpong K, Jamshed M, Kulama MAP. 2016. Genetic diversity studies on selected rice varieties grown in Africa based on aroma, cooking and eating quality. African Journal of Biotechonology. 15:1136-1146.

Suprihatno B, Daradjat AA, Satoto. 2010. Deskripsi varietas padi. Balai Besar Penelitian Tanaman Padi, Sukamandi, Subang.

Tan Y, Sun M, Corke H. 2002. Physicochemical properties of an elite rice hybrid. Journal of the Science of Food and Agriculture. 82:1628-1636.
Tian ZX, Yan CJ, Qian QA, Yan S, Xie HL, Wang F, Xu JF, Liu GF, Wang YH, Liu QQ, Tang SZ, Li YJ, Gu MH. 2010. Development of genetagged molecular markers for starch synthesis-related genes in rice. Chinese Science Bulletin. 55:3768-3777.

Yan C, Tian S, Zhang Z, Han Y, Chen F, Li X, Gu M. 2007. The source of genes related to rice grain starch synthesis among cultivated varieties and its contribution to quality. Agricultural Sciences in China. 6:129-136.

Zeng D, Yan MX, Wang YH, Liu XF, Qian Q, Li JY. 2007. Du1, encoding a novel Prp 1 protein regulates starch biosynthesis through affecting the specificity of $\mathrm{Wxb}$ pre-mRNAs in rice (Oryza sativa L.). Plant Molecular Biology. 65: 501-509. 